\title{
Mowing pasture to improve milk production
}

\author{
E.S. KOLVER, J.W. PENNO, K.A. MACDONALD, J.M. MCGRATH and W.A. CARTER \\ Dairying Research Corporation, Private Bag 3123, Hamilton, New Zealand
}

\begin{abstract}
Mowing pasture before grazing, and topping pasture after grazing were studied as methods to increase pasture quality, dairy cow dry matter intake, and milksolids production from September 1997 to February 1998. Three 2.8-ha experimental areas were subjected to mowing, topping, or control treatments, and were grazed by three Friesian cows/ha (18 cows per treatment). Cows were allocated to each treatment according to a crossover design and pastures were grazed every 28 days. Mowing pasture, either before or after grazing, reduced pasture production by $20 \%$, and reduced milksolids production by $11 \%$ during October, but increased milksolids production by $12 \%$ during summer. Liveweight change responded similarly; mowing or topping resulted in greater liveweight gain $(0.76 \mathrm{~kg} / \mathrm{cow} /$ day $)$ during summer compared with the control. This was associated with an increase in the metabolisable energy content of summer pastures that had been mown before grazing $(0.2$ $\mathrm{MJME} / \mathrm{kg} \mathrm{DM})$, or topped after grazing (0.6 $\mathrm{MJME} / \mathrm{kg} \mathrm{DM})$. Topping pastures after grazing reduced milksolids production in October by 0.11 $\mathrm{kg} \mathrm{MS} / \mathrm{cow} /$ day, and increased milksolids production in summer by $0.13 \mathrm{~kg} \mathrm{MS} / \mathrm{cow} /$ day. Mowing pasture before grazing increased average dry matter content of the wilted material by $7.5 \%$ units compared with the control, but dry matter intake was reduced by $2.4 \mathrm{~kg} \mathrm{DM} / \mathrm{cow} /$ day in November, and milksolids production was reduced by $0.12 \mathrm{~kg} \mathrm{MS} / \mathrm{cow} /$ day during spring. Mowing before grazing increased milksolids production in summer by $0.13 \mathrm{~kg} \mathrm{MS} / \mathrm{cow} /$ day. Overall, only the topping treatment increased total milksolids produced during the six 14-day experimental periods (by $80 \mathrm{~kg} \mathrm{MS}$, or $4.6 \%$ ). However, an additional $5184 \mathrm{~kg}$ of DM was removed from the control pastures by extra cows, which could have produced an additional $415 \mathrm{~kg}$ milksolids. Therefore, although mowing or topping can increase the quality of pasture and the yield of MS per cow in summer, the overall benefits for MS production per ha are small or negative.
\end{abstract}

Keywords: dairy cow, herbage mass, milksolids, milk yield, mowing, nutritive value, pasture intake, topping

\section{Introduction}

The stocking rate required to optimise the economic farm surplus (EFS) on dairy farms is generally lower than that required to optimise overall milk production. This is because most variable costs are directly related to the number of cows farmed (Penno 1998). To maintain or improve profitability by milking fewer cows, a higher dry matter (DM) intake per cow is needed to achieve high pasture utilisation and quality, especially during spring and early summer.

Achieving a greater intake of pasture, however, may be limited by the low DM content of high quality pasture (John \& Ulyatt 1987), and by the time and energy required to harvest pasture by grazing (Parsons et al. 1994). While mowing residual pasture after cows have been offered a high allowance can maintain pasture quality through the late spring (Holmes \& Hoogendoorn 1983; Hughes 1983), mowing and wilting pasture before grazings in spring and early summer may overcome the low DM content and harvesting efficiency factors limiting intake. This concept was tested by Bryant (1982) who showed that mowing pasture during spring improved milk production from October to March. Milksolids production from a high stocked farmlet system (4.36 Jerseys/ha) increased by $28 \mathrm{~kg} \mathrm{MS} / \mathrm{ha}$ with mowing before grazing, and by $66 \mathrm{~kg}$ MS/ha with topping after grazing. However, the high stocking rate used by Bryant (1982) may have constrained the DM intake and milk response of the cows. The present paper reports an experiment where a lower stocking rate (three Friesian cows/ha) than that used by Bryant (1982) was used to evaluate changes in DM intake, milk production, and herbage characteristics resulting from mowing pasture before grazing and from topping after grazing.

\section{Methods and materials}

\section{Treatments}

At the DRC No. 2 Dairy, three areas consisting of seven 0.4-ha paddocks were subjected to three treatments: (i) pasture mown 24 hours before grazing, 
(ii) pasture topped 24 hours after grazing, and (iii) a control that was not mown. The pasture was mown with a disc mower to a height of $7 \mathrm{~cm}$. The noncontiguous treatment areas were balanced for initial average herbage mass, soil type, and pasture growth potential (18 t DM/ha/year). Treatment areas were grazed by three Friesian cows/ha $(72 \mathrm{~kg}$ liveweight $/ \mathrm{t}$ DM grown). Cows $(n=18)$ were blocked by age, breeding worth, milk production, and liveweight, and were allocated to treatments according to a crossover design. The pastures were grazed at intervals of 28 days during spring (September, October, November 1997) and summer (December 1997, January, and February 1998), resulting in six experimental periods of 14 days. Each experimental period consisted of an adjustment week from day 1 to 7 , and a measurement week from day 8 to 14 . The experimental pastures were grazed over periods of 14 days, while all the cows were removed for the other 14 days and were grazed together as one group on other non-experimental pastures. Two cows were removed from the experiment before the November experimental period, as one had a cut teat and the other was required for another experiment. Before the February experimental period, 16 cows were removed from the experiment as cull cows, leaving 12 cows per treatment. Pastures were not mown or topped during the February experimental period due to high pasture DM content and low average herbage mass. No silage was harvested from any of the treatments, but the control treatment area received an additional grazing with 54 non-experimental animals after the December experimental period to reduce the average herbage mass. Six paddocks were grazed during 6 days, and cows consumed an estimated $5184 \mathrm{~kg}$ DM.

\section{Measurements}

Pasture: Average herbage mass of each treatment area was estimated by calibrated visual assessment at the start of each experimental period. Visual calibrations were made weekly from twelve, $0.33 \mathrm{~m}^{2}$ quadrats representative of the current pre- and post-grazing herbage mass. Visual estimates of the herbage mass of each quadrat were made, and herbage was cut to ground level, washed and dried at $95^{\circ} \mathrm{C}$ for 48 hours, and the measured herbage mass regressed against the visual estimate of herbage mass. During each experimental period, pasture samples from the currently grazed paddock were randomly collected by daily hand-clipping to grazing height. On treatment areas where pasture was mown before grazing, pasture samples were collected from standing pasture and also from the subsequent mown pasture that had been wilted for 24 hours. Samples for each treatment were bulked within each experimental period and near-infrared spectroscopy
(Ulyatt et al. 1995) was used to analyse in vitro organic matter digestibility (IVD), metabolisable energy (ME), crude protein (CP), neutral detergent fibre (NDF), and nonstructural carbohydrates (NSC) contents. Samples were also analysed for alkane content (Dove \& Mayes 1991).

Pasture intake: Herbage intake of each of the three herds was estimated by calibrated visual assessment of daily DM disappearance. Individual cow DM intake was estimated during the last 5 days of the September and November experimental periods using an alkane technique (Dove \& Mayes 1991). During the first experimental period (September 1997) individual intakes of cows grazing pasture topped after grazing were not measured, since no previous mowing treatment had been imposed and the pasture was the same as in the control treatment. Capsules containing synthetic C32 and C36 alkanes were administered to cows twice daily for 10 days. Individual faecal samples, collected twice daily at 06.30 and 14.30 hours on the last 5 days of each experimental period, were bulked and analysed for alkane content.

Animals: Individual milk yield and composition (fat, protein, and lactose) were measured daily ( $\mathrm{pm}+\mathrm{am}$ milking) during the last 5 days of each experimental period. Liveweight (LW) was measured on two consecutive days at the beginning and end of each 14day experimental period.

\section{Statistical analysis}

Milk production and composition, liveweight change and DM intake determined from alkane markers were analysed using the mixed models procedure in SAS (Version 6) according to the model:

$$
\begin{aligned}
& \mathrm{Y}_{\mathrm{ij}}=\mu+\text { Period }_{\mathrm{i}}+\text { Treatment }_{\mathrm{j}}+\text { Block }_{\mathrm{k}(\mathrm{ij})}+ \\
& (\text { Cow }(\text { Block }))_{\mathrm{lk}(\mathrm{ij})}+(\text { Period.Treatment })_{\mathrm{ij}}+\mathrm{e}_{\mathrm{ij}}
\end{aligned}
$$

Mean herbage mass, pasture growth rate, and DM intake estimated from DM disappearance were analysed using the model:

$$
\mathrm{Y}_{\mathrm{ij}}=\mu+\text { Block }_{\mathrm{i}}+\text { Treatment }_{\mathrm{j}}+\mathrm{e}_{\mathrm{ij}}
$$

\section{Results}

\section{Chemical composition}

Compared with standing pasture measured before mowing, mown and wilted pasture had a higher DM content (by an average of $7.5 \%$ units during spring and summer $(\mathrm{P}<0.001)$ ), a lower ME content (by $0.6 \mathrm{MJ}$ $\mathrm{ME} / \mathrm{kg} \mathrm{DM}$ ), a lower IVD (by $4 \%$ units) and NSC 
content (by $1.5 \%$ units), and a higher NDF content (by $2 \%$ units) (Table 1). Compared with the control, mowing before grazing did not change ME content in spring, but increased pasture quality by an average of $0.2 \mathrm{MJ}$ $\mathrm{ME} / \mathrm{kg} \mathrm{DM}$ during summer. Topping pasture after grazing consistently increased the quality of pasture by $0.6 \mathrm{MJ} \mathrm{ME} / \mathrm{kg}$ DM during spring and summer.

\section{Herbage mass}

Compared with the control, both the mowing and the topping treatments reduced herbage mass throughout spring and summer by an average of $20 \%(696 \mathrm{~kg} \mathrm{DM} /$ ha; $\mathrm{P}<0.05$ ) (Table 2). A similar herbage mass was observed for both the mowing and topping treatments from September to February. Mowing before grazing, and topping after grazing, both reduced calculated pasture growth rates during October $(\mathrm{P}<0.001)$ and November $(\mathrm{P}<0.05)$, but increased calculated growth rates during January $(\mathrm{P}<0.01)$, compared with the control. Mean pasture allowance during the six experimental periods was 47,39 , and $39 \mathrm{~kg} \mathrm{DM} / \mathrm{cow} /$ day for the control, mowing, and topping treatments (data not shown).

\section{Milk yield and composition}

Compared with the control, mowing pasture before grazing reduced the yields of milk and milksolids during spring by an average of $1.55 \mathrm{l} / \mathrm{cow} /$ day $(\mathrm{P}<0.05)$ and $0.12 \mathrm{~kg} \mathrm{MS} /$ cow/day $(\mathrm{P}<0.05)$, respectively (Table 3$)$. However, yields of milk and milksolids were increased during summer by an average of $1.461 /$ cow/day $(\mathrm{P}<0.05)$ and $0.11 \mathrm{~kg} \mathrm{MS} / \mathrm{cow} /$ day $(\mathrm{P}<0.05)$, respectively. Mowing before grazing had no effect on milkfat content during spring, but reduced it during February $(\mathrm{P}<0.05)$. Milk protein content was reduced during October $(\mathrm{P}<0.001)$ and increased during January $(\mathrm{P}<0.001)$.

Topping pastures after grazing produced similar milk production responses in spring and summer; yields

Table 1 Chemical composition (dry matter (DM)\%, estimated metabolisable energy (MJ ME/kg DM), in vitro organic matter digestibility (IVD)\%, crude protein (CP)\%, neutral detergent fibre (NDF)\%, nonstructural carbohydrate (NSC)\%) of control pasture, pasture mown before grazing, and pasture topped after grazing. Measure of variability available only for DM\%.

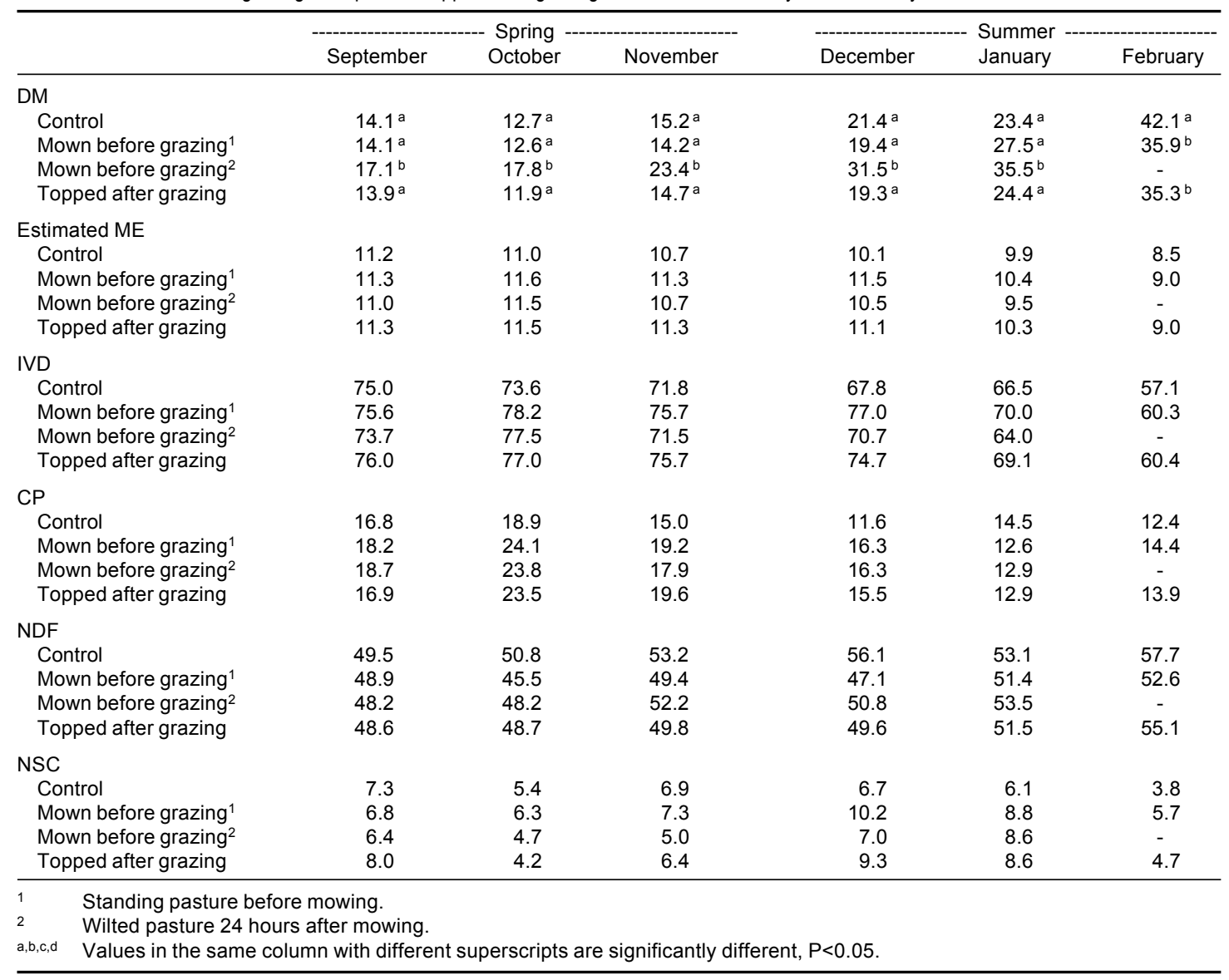


of milk and milksolids during October were reduced by $1.55 \mathrm{l} / \mathrm{cow} /$ day $(\mathrm{P}<0.05)$ and $0.11 \mathrm{~kg} \mathrm{MS} / \mathrm{cow} /$ day $(\mathrm{P}<0.05)$, respectively. However, yields of milk and milksolids were increased during summer by an average of $1.75 \mathrm{l} / \mathrm{cow} /$ day $(\mathrm{P}<0.05)$ and $0.13 \mathrm{~kg} \mathrm{MS} / \mathrm{cow} /$ day $(\mathrm{P}<0.05)$, respectively, compared with the control. Topping after grazing increased milkfat content during September $(\mathrm{P}<0.05)$ and January $(\mathrm{P}<0.05)$, but reduced milkfat content in February $(\mathrm{P}<0.01)$. Milk protein content in spring was not changed by topping after grazing, but was increased during December $(\mathrm{P}<0.01)$ and January $(\mathrm{P}<0.05)$, compared with the control.

Topping pastures after grazing resulted in a mean milksolids production of $1.28 \mathrm{~kg} \mathrm{MS} / \mathrm{cow} /$ day across the six 14-day experimental periods. This mean milksolids production was greater $(\mathrm{P}<0.05)$ than that for the control (1.22 $\mathrm{kg} \mathrm{MS} / \mathrm{cow} /$ day) and the premown $(1.21 \mathrm{~kg} \mathrm{MS} /$ cow/day) treatments.

The effects of mowing or topping treatments on liveweight were generally consistent with the trends in yields of milksolids; during spring, cows grazing pasture which had been mown before grazing lost more liveweight than the control cows, the difference being $0.77 \mathrm{~kg} / \mathrm{cow} /$ day $(\mathrm{P}<0.01)$. During summer however, mowing pasture before grazing resulted in a higher average liveweight gain, the difference being $0.78 \mathrm{~kg} /$ cow/day $(\mathrm{P}<0.01)$. Similar differences $(\mathrm{P}<0.01)$ were observed for cows grazing pasture that had been topped after grazing.

Table 2 Mean herbage mass ( $\mathrm{kg} \mathrm{DM} / \mathrm{ha}$ ) and estimated pasture growth rate $(\mathrm{kg} \mathrm{DM} / \mathrm{ha} /$ day) of the control pasture, pasture mown before grazing, and pasture topped after grazing.

\begin{tabular}{|c|c|c|c|c|c|c|}
\hline & \multicolumn{3}{|c|}{ 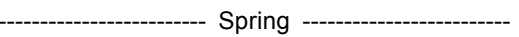 } & \multirow{2}{*}{\multicolumn{2}{|c|}{$\begin{array}{ll}\text { December } & \text { Summer } \\
\text { January }\end{array}$}} & \multirow{2}{*}{ February } \\
\hline & September & October & November & & & \\
\hline \multicolumn{7}{|l|}{ Herbage mass } \\
\hline Control & $2743^{a}$ & $2732^{a}$ & $3836^{a}$ & $4329^{a}$ & $3792^{a}$ & $3932^{a}$ \\
\hline Mown before grazing & $2560^{b}$ & $2432^{b}$ & $2764^{b}$ & $3011^{b}$ & $3354^{b}$ & $3204^{b}$ \\
\hline Topped after grazing & $2400^{b}$ & $2389^{b}$ & $2764^{b}$ & $2936^{b}$ & $3421^{b}$ & $3150^{b}$ \\
\hline \multicolumn{7}{|l|}{ Pasture growth rate } \\
\hline Control & - & $52^{a}$ & $89^{a}$ & $56^{a}$ & $61^{a}$ & $10^{a}$ \\
\hline Mown before grazing & - & $34^{b}$ & $76^{b}$ & $61^{a}$ & $70^{b}$ & $18^{a}$ \\
\hline Topped after grazing & - & $29^{b}$ & $75^{b}$ & $49^{a}$ & $77^{\mathrm{b}}$ & $10^{a}$ \\
\hline
\end{tabular}

Table 3 Milk yield (I/cow/day), milk composition (fat\% and protein $\%$ ), milksolids yield ( $\mathrm{kg} / \mathrm{cow} / \mathrm{day})$, and change in liveweight ( $\mathrm{kg} / \mathrm{cow} / \mathrm{day}$ ) of cows grazing control pasture, pasture mown before grazing, and pasture topped after grazing.

\begin{tabular}{|c|c|c|c|c|c|c|}
\hline & \multicolumn{3}{|c|}{ 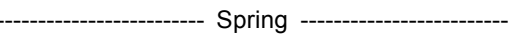 } & \multicolumn{3}{|c|}{ 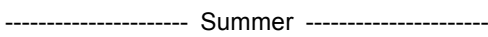 } \\
\hline & September & October & November & December & January & February \\
\hline \multicolumn{7}{|l|}{ Milk yield } \\
\hline Control & $19.48^{a}$ & $18.98^{\mathrm{a}}$ & $17.81^{\mathrm{a}}$ & $14.97^{\mathrm{a}}$ & $13.06^{a}$ & $8.18^{\mathrm{a}}$ \\
\hline Mown before grazing & $18.59^{b}$ & $16.19^{b}$ & $16.84^{b}$ & $15.70^{a}$ & $14.73^{b}$ & $10.17^{b}$ \\
\hline Topped after grazing & $19.57^{\text {a }}$ & $17.43^{c}$ & $18.20^{\mathrm{a}}$ & $16.57^{\mathrm{b}}$ & $14.99^{\mathrm{b}}$ & $9.91^{b}$ \\
\hline \multicolumn{7}{|l|}{ Fat $\%$} \\
\hline Control & $4.29^{a}$ & 4.42 & 4.46 & $4.63^{a}$ & $4.59^{\mathrm{a}}$ & $5.13^{a}$ \\
\hline Mown before grazing & $4.32^{\mathrm{a}}$ & 4.50 & 4.52 & $4.50^{b}$ & $4.65^{\mathrm{ab}}$ & $4.96^{\mathrm{b}}$ \\
\hline Topped after grazing & $4.46^{b}$ & 4.48 & 4.42 & $4.61 \mathrm{ab}$ & $4.74^{b}$ & $4.87^{b}$ \\
\hline \multicolumn{7}{|l|}{ Protein $\%$} \\
\hline Control & $3.40^{\mathrm{a}}$ & $3.46^{\mathrm{a}}$ & $3.42^{\mathrm{a}}$ & $3.35^{a}$ & $3.35^{\mathrm{a}}$ & $3.29^{a}$ \\
\hline Mown before grazing & $3.42^{a}$ & $3.31^{\mathrm{b}}$ & $3.38^{a}$ & $3.41^{a b}$ & $3.49^{b}$ & $3.26^{a}$ \\
\hline Topped after grazing & $3.37^{a}$ & $3.41^{\mathrm{a}}$ & $3.40^{\mathrm{a}}$ & $3.46^{b}$ & $3.44^{b}$ & $3.28^{a}$ \\
\hline \multicolumn{7}{|l|}{ Milksolids } \\
\hline Control & $1.49 a b$ & $1.49^{a}$ & $1.41^{\mathrm{a}}$ & $1.18^{a}$ & $1.02^{\mathrm{a}}$ & $0.71^{a}$ \\
\hline Mown before grazing & $1.43^{a}$ & $1.26^{\mathrm{b}}$ & $1.33^{b}$ & $1.24^{\mathrm{a}}$ & $1.19^{b}$ & $0.81^{b}$ \\
\hline Topped after grazing & $1.54^{\mathrm{b}}$ & $1.38^{c}$ & $1.41^{\mathrm{a}}$ & $1.33^{b}$ & $1.22^{b}$ & $0.78^{a b}$ \\
\hline \multicolumn{7}{|l|}{ Liveweight change } \\
\hline Control & $0.08^{a}$ & $0.13^{a}$ & $0.69^{a}$ & $0.84^{a}$ & $-0.63^{a}$ & $-0.86^{a}$ \\
\hline Mown before grazing & $-0.17^{a}$ & $-1.34^{b}$ & $0.10^{b}$ & $1.03^{a}$ & $0.71^{\mathrm{b}}$ & $-0.05^{b}$ \\
\hline Topped after grazing & $0.47^{b}$ & $-0.99^{c}$ & $0.48^{a}$ & $1.03^{a}$ & $0.56^{b}$ & $-0.04^{b}$ \\
\hline
\end{tabular}

a,b,c,d Values in the same column with different superscripts are significantly different, $P<0.05$. 
Table 4 Dry matter (DM) intake (kg/cow/day) of cows grazing control pasture, pasture mown before grazing, and pasture topped after grazing. Intake determined by the alkane technique (September and November) and the pre- and post-grazing technique (October, December, January, and February, and the topping treatment in September).

\begin{tabular}{|c|c|c|c|c|c|c|}
\hline & \multicolumn{3}{|c|}{------------------------ Spring ------------------------ } & \multicolumn{3}{|c|}{----1--1 } \\
\hline & September & October & November & December & January & February \\
\hline \multicolumn{7}{|l|}{ DM Intake } \\
\hline Control & $13.2^{\mathrm{a}}$ & $16.2^{\mathrm{a}}$ & $18.3^{a}$ & $12.7^{\mathrm{a}}$ & $16.4^{\mathrm{ab}}$ & $12.1^{\mathrm{a}}$ \\
\hline Mown before grazing & $12.8^{\mathrm{a}}$ & $20.2^{\mathrm{b}}$ & $15.9^{b}$ & $16.9^{b}$ & $17.6^{\mathrm{a}}$ & $12.9^{a}$ \\
\hline Topped after grazing & $13.3^{a}$ & $16.8^{\mathrm{a}}$ & $17.8^{\mathrm{a}}$ & $14.6^{c}$ & $13.6^{b}$ & $12.9^{a}$ \\
\hline
\end{tabular}

a,b,c,d Values in the same column with different superscripts are significantly different, $\mathrm{P}<0.05$

\section{Pasture intake}

When the alkane technique was used to estimate DM intake, the only significant effect of treatments was that mowing pasture before grazing significantly reduced DM intake by $2.4 \mathrm{~kg} \mathrm{DM} /$ cow/day in November $(\mathrm{P}<0.05)$. Dry matter intake was more difficult to estimate from DM disappearance than from the alkane technique, especially for the mowing and topping treatments. Estimates of DM disappearance indicated that the mowing treatment resulted in a higher DM intake than the control or mowing treatments in October $(\mathrm{P}<0.05)$, and that both mowing and topping treatments resulted in a higher DM intake than the control during December $(\mathrm{P}<0.05)$ (Table 4). In January, the topping treatment resulted in a significantly lower DM intake compared with the mowing treatment $(\mathrm{P}<0.05)$.

\section{Discussion}

Mowing pasture, either before or after grazing, reduced pasture production by $20 \%$ during September to February and reduced milksolids production in October, but increased milksolids production by $12 \%$ through the summer period compared with the control. The reduced milksolids production in October was likely due to lower herbage masses, whereas the improved milksolids production during summer was a function of improved pasture quality as DM intake was broadly similar across the three treatments. These results are similar to those of Bryant (1982) who reported that mowing pasture before grazing or topping after grazing from October to December produced a 5.5\% and 8.2\% increase in milksolids, respectively, during the following January to March. As in the present experiment, this trial showed that topping, and to a lesser extent mowing before grazing, improved pasture quality and improved milksolids production in summer. The summer milksolids response in the present experiment was driven by higher milk yields, a lower milkfat content and a generally higher protein content, reflecting pasture which contained more ME and less fibre.
The mean reduction in herbage mass $(696 \mathrm{~kg} \mathrm{DM} /$ ha) on both mowing and topping treatments compared with the control was consistent with the $165 \mathrm{~kg} \mathrm{DM} / \mathrm{ha}$ reduction in farm pasture cover estimated by Bryant (1982), since we used a lower stocking rate. Holmes \& Hoogendoorn (1983) also noted that topping in spring reduced pasture yield, and that this reduction was $31 \%$ greater for lax-grazed pastures than for hard-grazed pastures. The reduced pasture cover was likely a result of lower pasture growth rates and removal of herbage by cutting and decay. In the present experiment growth rates for both mowing treatments in October and November were approximately $17 \mathrm{~kg} \mathrm{DM} / \mathrm{ha} /$ day less than the control. January growth rates of mown and topped pasture were $12.5 \mathrm{~kg} \mathrm{DM} /$ ha/day higher than the control. The positive association between herbage mass and growth rate in spring, and the negative association during summer, was also reported by Hoogendoorn et al. (1992).

The monthly average herbage masses (Table 2) may be regarded as being high. However this is an artifact of the experimental design which required cows to graze the treatment pastures for 14 days during the experimental periods, and then graze non-treatment pastures for the next 14 days. This resulted in average herbage masses for the experimental periods (Table 2) being based only on 14 to 28 -day regrowth, and did not include the shorter 0 to 13 -day regrowth present on the non-experimental pastures.

The reduction in milksolids production on the mowing treatment during October and November was unexpected, but concurs with the 2.4-kg lower DM intake estimated by alkane technique in November. Although Bryant (1982) observed an increased herd DM intake when pasture was mown before grazing (2.2 $\mathrm{kg} \mathrm{DM} / \mathrm{cow} /$ day), milksolids production was not improved. The present experiment measured pasture quality and found that mowing and wilting pasture before grazing generally had a negative effect on feed quality by reducing ME content, IVD, and NSC content, and increasing fibre content. These changes reflect physiological changes in the wilted pasture, as well as 
the effects of including some pasture of poorer quality that would not normally have been consumed by the cow. Despite these changes, the mown and wilted pasture was of similar quality to the control pasture during spring. The reduced DM intake of cows grazing wilted pasture may have resulted from reduced pasture palatability, caused by rainfall on the wilted pasture. In spring (September, October, November 1997), a total of $273 \mathrm{~mm}$ of rain fell on 54 days. If rain does reduce the palatability of wilted pasture, then results from this experiment may represent a typical year, as the rainfall during spring 1997 was similar to the 92-year spring average of $273 \mathrm{~mm}$ of rain falling on 48 rain days (NIWA pers. comm.).

These data also highlight how environmental events, such as rain or temperature, may confound increases in DM content derived from wilting. In September, the wettest month (132 $\mathrm{mm}$ of rain), wilting increased DM content by only $3 \%$ units, whereas in December (59 $\mathrm{mm}$ of rain), DM content was increased by $12 \%$ units after wilting. The increase in DM content achieved in this experiment was, however, theoretically sufficient to increase DM intake, since John \& Ulyatt (1987) showed that voluntary consumption of fresh grass was positively correlated with pasture DM content over a wide range $(12-25 \%)$ of DM contents. This suggests that some factor, perhaps reduced palatability, constrained the DM intake of cows grazing wilted pasture.

Mowing pasture, either before or after grazing, has become common practice on New Zealand dairy farms in an attempt to maintain high pasture quality into the summer. In this experiment, topping pasture after grazing did not reduce milksolids production during spring to the same extent as did mowing before grazing, but the topping treatment increased pasture quality, milksolids production, and liveweight during summer. Overall, the herd grazing pastures topped after grazing produced a total of $1809 \mathrm{~kg}$ MS during the six 14-day experimental periods (September to February). The total milksolids production was $80 \mathrm{~kg}$ MS (4.6\%) greater than the control herd which produced a total of 1729 $\mathrm{kg}$ MS, and the herd grazing wilted pasture which produced $1708 \mathrm{~kg}$ MS. Data from Bryant (1982) indicated similar responses of $28 \mathrm{~kg} \mathrm{MS} / \mathrm{ha}$ and $66 \mathrm{~kg}$ MS/ha achieved by mowing before, or after grazing, respectively. In the present experiment, topping increased overall milksolids production and cows weighed a mean of $18 \mathrm{~kg}$ more than the control cows during the six 14-day experimental periods. The extra liveweight was equivalent to an extra $54 \mathrm{~kg}$ MS for the herd grazing topped pastures during the six 14-day experimental periods (assuming a marginal milk response of $80 \mathrm{~g} \mathrm{MS} / \mathrm{kg} \mathrm{DM})$. However, more pasture was grown on the control farm, and an additional 5184 $\mathrm{kg}$ of DM was harvested by non-experimental cows. The additional pasture that was harvested was equivalent to $415 \mathrm{~kg}$ MS (assuming a marginal milk response of $80 \mathrm{~g} \mathrm{MS} / \mathrm{kg} \mathrm{DM}$ ). This would have resulted in a total milksolids production of $2144 \mathrm{~kg}$ MS from the control treatment during the six 14-day experimental periods from September to February period, which would have negated the improvements in milksolids production achieved by topping. Despite the additional grazing, herbage mass remained higher on the control pastures. Even more pasture could have been removed by further grazing, or harvested as silage, with potentially more milksolids produced. Without the harvesting ability of higher stocked farms, topping and conservation for silage become even more critical for the maintenance of pasture quality on lower stocked farms.

\section{Conclusions}

Mowing or topping improved pasture quality and milksolids production during summer, but total DM production was reduced, especially during spring. The herd grazing the topped pasture produced $4.6 \%$ more milksolids ( $80 \mathrm{~kg}$ total MS per six 14-day experimental periods) compared with herds grazing the control pastures and pastures mown before grazing. Importantly, a potential $415 \mathrm{~kg}$ MS could have been produced from the additional pasture that was grown and harvested on the control area. The additional milksolids production from the control treatment is greater than the additional milksolids obtained by topping. Wilting pasture increased DM content, but did not appear to increase DM intake or milksolids production during spring, presumably as a result of reduced palatability. The focus for dairy farmers should remain on the removal of grazing area for harvest as silage to capture potential pasture production, and to increase grazing pressure to maintain recommended grazing residuals during the late spring. These results show that topping or mowing moderately stocked pastures will provide little benefit compared with grazed pasture that is not mown or topped. If mowing is to be used, it is best to mow after the cows have grazed a paddock, particularly during spring.

\section{ACKNOWLEDGEMENTS}

The authors thank staff at DRC No. 2 Dairy, for animal management and measurements, Glenise Ferguson for assistance with sample preparation, Ross McKee, Paul Sutherland, and Jewel Jackson for alkane analysis, and Rhonda Hooper for statistical analyses. 


\section{REFERENCES}

Bryant, A.M. 1982. Effects of mowing before or after grazing on milk production. Proceedings of the Conference on Dairy Production from Pasture, New Zealand and Australian Societies of Animal Production: 381-382.

Dove, H.; Mayes, R.W. 1991. The use of plant wax alkanes as marker substances in studies of the nutrition of herbivores: a review. Australian journal of agricultural research 42: 913-952.

Holmes, C.W.; Hoogendoorn, C.J. 1983. Some effects of grazing management in early lactation, and of topping on the growth and quality of pasture. Dairyfarming Annual 35: 36-43.

Hoogendoorn, C.J.; Holmes, C.W., Chu, A.C.P. 1992. Some effects of herbage composition, as influenced by previous grazing management, on milk production by cows grazing on ryegrass-white clover pastures. 2. Milk production in late spring-summer: effects of grazing intensity during the preceding spring period. Grass and forage science 47: 316-325.
Hughes, T.P. 1983. Late spring grazing management. Proceedings of the Lincoln College Farmers' Conference 33: 18-21.

John, A.; Ulyatt, M.J. 1987. Importance of dry matter content to voluntary intake of fresh grass forages. Proceedings of the New Zealand Society of Animal Production 47: 13-16.

Parsons, A.J.; Thornley, J.H.M.; Newman, J.A.; Penning P.D. 1994. A mechanistic model of some physical determinants of intake rate and diet selection in a two species temperate grassland sward. Functional ecology 8: 187-204.

Penno, J.W. 1998. Pasture utilisation in dairy farming systems. Proceedings of the Society of Dairy Cattle Veterinarians of the New Zealand Veterinary Association 75: 165-174.

Ulyatt, M.J.; Lee, J.; Corson, D. 1995. Assessing feed quality. Proceedings of the Ruakura Farmers' Conference 47: 63-70. 
